\title{
Sistem Informasi Promosi Produk : Studi Pada Usaha Kecil Menengah Kota Bengkalis
}

\author{
Kasmawi $^{1}$, Mansur ${ }^{2}$, Diah Angraina Fitri ${ }^{3}$ \\ 1,2,3 Program studi Teknik Informatika Jurusan Teknik Informatika Politeknik Negeri Bengkalis \\ Jl. Bathin Alam, Sungai Alam, Bengkalis, Riau, telp. (+62766) 24566, 24577 \\ e-mail: ${ }^{1}$ kasmawi@polbeng.ac.id, ${ }^{2}$ mansur@ polbeng.ac.id , ${ }^{3}$ diahfitri@ polbeng.ac.id
}

\begin{abstract}
Abstrak
Pemanfaatan teknologi informasi dapat membantu pemasaran produk Usaha Kecil Menengah (UKM) secara maksimal dengan memanfaatkan website dan akses internet untuk mengakses pasar dan mempromosikan produk. Sistem promosi produk UKM di Kabupaten Bengkalis dilakukan dengan cara konvensional yaitu promosi melalui kedai-kedai, di tokotoko/swalayan, ataupun berupa informasi melalui kerabat atau teman. Hal ini akan berpengaruh terhadap omset pada UKM. Selain itu sumber daya manusia dibidang TI masih sangat rendah. Penelitian ini bertujuan untuk membangun sistem informasi promosi produk berbasis web untuk meningkatkan promosi produk UKM di Kota Bengkalis. Informasi yang diberikan berupa informasi produk pada semua kategori, promosi produk-produk unggulan, dan promosi toko-toko yang berkaitan dengan produk yang dipromosikan.
\end{abstract}

Kata kunci: UKM, Promosi produk, Sistem Informasi

\section{Abstract}

The ulitization of information techonology can help marketing Small Medium Enterprises (SMEs) products maximally by utilizing website and internet access to access market and promote product. SMEs product promotion system in Bengkalis Regency is done by conventional means of promotion through shops, in store or supermarkets or in the form of information through relatives or friends. This will affect the turnover of SMEs in addition, human resources in the information thecnology (IT) filed is still very low. This research aims to build a web based product information promotion system to improve the promotin of SMEs products of the city of Bengkalis. Information provided for the form of product information about all categories, promotion of superior products, and promotion of stores related to the product being promoted.

Keywords: Small and Medium Enterprises (SMEs), Product Promotion, Information System

\section{Pendahuluan}

Usaha Kecil Menengah (UKM) merupakan salah satu organisasi atau kelompok usaha yang bertujuan untuk membantu meningkatkan perekonomian di Indonesia. Sistem promosi produk diberbagai daerah di Indonesia dilakukan di beberapa UKM di berbagai daerah Indonesia masih secara manual. Hal ini disebabkan oleh belum ada sarana yang memadai dalam mempromosikan produk secara terpadu, sehingga berakibat pada omset UKM yang belum optimal [1]. Selain itu, daya saing UKM di Indonesia terlihat rendah, sehingga banyak hal yang harus dilakukan oleh pemerintah, terutama pemerintah daerah, antara lain : pemberdayaan kembali semua sentra-sentra UKM, membantu perkembangan UKM lebih pada pendidikan dibidang IT dan pengusaha, serta diupayakan semua UKM dimanapun berada mendapatkan akses ke informasi mengenai pasar dan teknologi [2]. Jika kita lihat jumlah UKM di Provinsi Riau, kabupaten Bengkalis (42.029 UKM) menempati posisi ke-empat se-provinsi Riau setelah Pekanbaru (68.728 UKM), Kampar (45.446 UKM) dan Inhil (44.891 UKM) [3]. 
Produk, promosi, harga dan distribusi merupakan faktor-faktor yang mempengaruhi keputusan pembelian konsumen terhadap suatu produk. Promosi merupakan salah satu faktor penentu keberhasilan suatu proses di pemasaran, sehingga promosi sangat penting dalam proses jual-beli. Produk merupakan atribut berwujud ataupun tidak berwujud, yang didalamnya terdapat warna, harga, nama barang dan nama toko yang menjualnya, yang diterima oleh pembeli untuk memuaskan keinginannya [4]. Menurut Swastha dan Irawan, promosi merupakan arus informasi satu arah yang mengarahkan seseorang atau perusahaan pada tindakan yang menciptakan proses pertukaran dalam pemasaran [5]. Sejenis komunikasi yang memberikan keterangan yang meyakinkan pembeli/calon konsumen tenaga barang/jasa. Promosi ini bertujuan untuk memperoleh perhatian, mengingatkan dan meyakinkan calon pembeli suatu produk [6]. peranan strategii promosi dalam suatu usaha sangatlah penting untuk meningkatkan omset penjualan sehingga menimbulkan proses berkelanjutan, karena promosi dapat menimbulkan rangsangan kegiatan selanjutnya dari organisasi atau perusahaan [7].

Promosi produk UKM di Kota Bengkalis dilakukan dengan cara melakukan promosi melalui kedai-kedai, toko-toko/swalayan, ataupun berupa informasi melalui kerabat atau teman. Sistem promosi tersebut dilakukan dengan cara konvensional. Hal ini akan berpengaruh pada omset yang dihasilkan oleh UKM itu sendiri. Hal ini mengakibatkan omset pada UKM belum optimal atau maksimal dan berpengaruh terhadap sistem penyediaan produk. Selain itu tingkat pemahaman para pelaku UKM Kabupaten Bengkalis terhadap pemanfaatan teknologi informasi dalam promosi produk sangat rendah. Beberapa faktor yang mempengaruhi tingkat pemahaman pelaku UKM terhadap teknologi informasi dan minimnya sistem promosi produk berbasis internet. Ada beberapa cara pemanfaatan teknologi informasi dalam penguatan promosi produk UKM yaitu : penggunaan media sosial, website, akses internet untuk mengetahui perkembangan pasar, memberikan layanan tanpa batas waktu, dan penggunaan transaksi bisnis cash on delivery [8][10]. Untuk itu, desain aplikasi promosi berbasis web dapat membantu UKM dalam memperluas promosi produk dalam meningkatkan pendapatan UKM [9].

Penelitian ini bertujuan untuk membangun rancangan aplikasi berbasis web guna untuk meningkatkan promosi produk UKM pada semua kategori di wilayah Kota Bengkalis. Informasi yang diberikan berupa informasi produk pada semua kategori, promosi produk-produk unggulan, dan promosi toko-toko yang berkaitan dengan produk yang dipromosikan.

\section{Metode Penelitian}

Tahapan yang digunakan dalam penelitian ini terdiri dari identifikasi masalah, pengumpulan data untuk kebutuhan sistem, desain sistem, uji coba sistem dan hasil desain sistem informasi promosi produk UKM. Pengumpulan data dilakukan pada 7 UKM yang ada di dua kecamatan pada kota Bengkalis. Pengumpulan data dilakukan dengan cara:

1. Observasi; pengumpulan data melalui observasi dilakukan dengan cara mengamati secara langsung UKM tersebut.

2. Wawancara; untuk mendapatkan beberapa informasi yang berhubungan dengan penerapan media pemasaran online yang dilakukan oleh UKM.

3. Kajian Pustaka; pengumpulan data dengan cara kajian pustaka didapatkan dari berbagai sumber seperti jurnal, buku dan internet. Kajian pustaka ini sangat penting untuk mengulas kembali beberapa penelitian yang telah dilakukan oleh para peneliti terdahulu tentang pengelolaan database, Media Promosi Online. Tahapan penelitian dapat dilihat pada Gambar 1. 


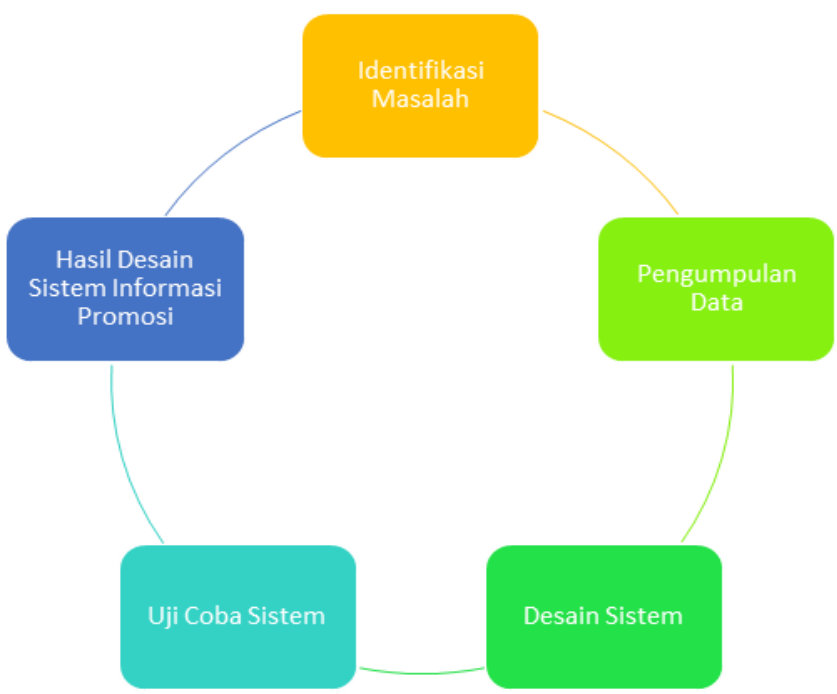

Gambar 1. Prosedur Penelitian

\section{Hasil dan Pembahasan}

\subsection{Analisa Sistem}

\subsubsection{Analisa sistem promosi produk UKM}

Sistem promosi produk berdasarkan hasil tinjauan langsung ke 7 UKM di Bengkalis yaitu : UKM Kub Kemas Wonosari, UKM Tenun Bersaudara, UKM WD Hijab, UKM D\&A Collection, Gadget Aksesoris, Batik Game dan UKM Mie Sagu Alami. Hasil tinjauan di 7 UKM ditemukan sistem promosi produk yang dilakukan secara konvensional. Sistem promosi yang dilakukan dengan cara membuat pamplet, brosur, dan menyampaikan informasi secara perorang atau kelompok. Sedangkan, hasil produk UKM dijual melalui sistem penitipan di toko-toko atau kedai-kedai, swalayan dan warung. Jika dilihat dari sumber daya manusia (SDM) terhadap penggunaan teknologi informasi dapat ditemukan masing-masing UKM memiliki peralatan yang mendukung bidang information techonology (IT). Namun, pemanfaatan IT belum dilakukan secara optimal. Sehingga hal tersebut mengakibatkan keterbatasan pada promosi dan penjualan produk UKM. Sistem promosi produk secara konvensional pada 7 UKM dapat dilihat pada Gambar 2.

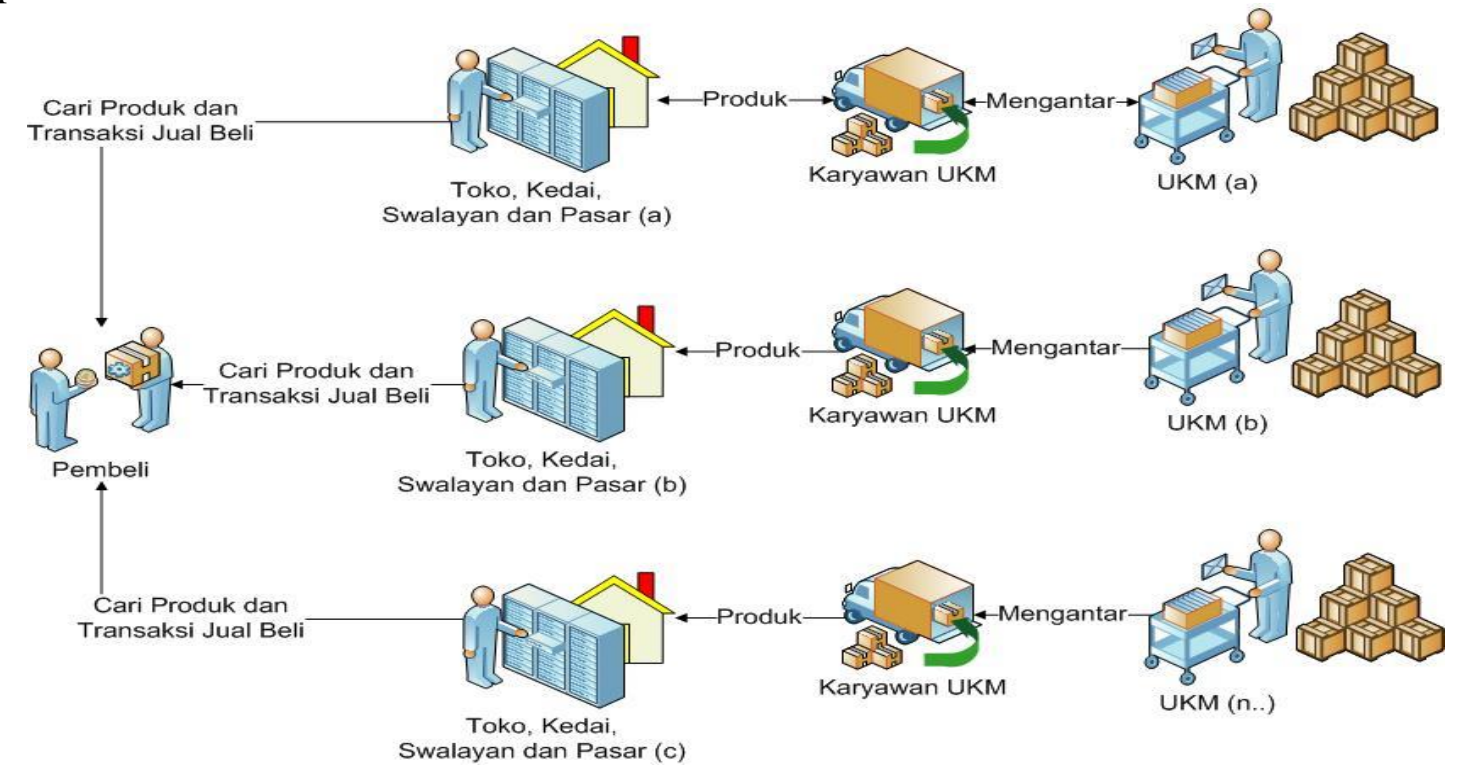

Gambar 2. Sistem Promosi Produk Secara Konvensional 


\subsubsection{Analisa Usulan Sistem Promosi Produk UKM}

Untuk peningkatan sistem promosi dan penjualan produk UKM dilakukan pengembangan sistem promosi dan penjualan produk UKM dengan cara yaitu menggabungkan sistem promosi menggunakan IT dan sistem promosi konvensional. Proses bisnis pengembangan sistem promosi produk UKM dapat dilihat pada Gambar 3.

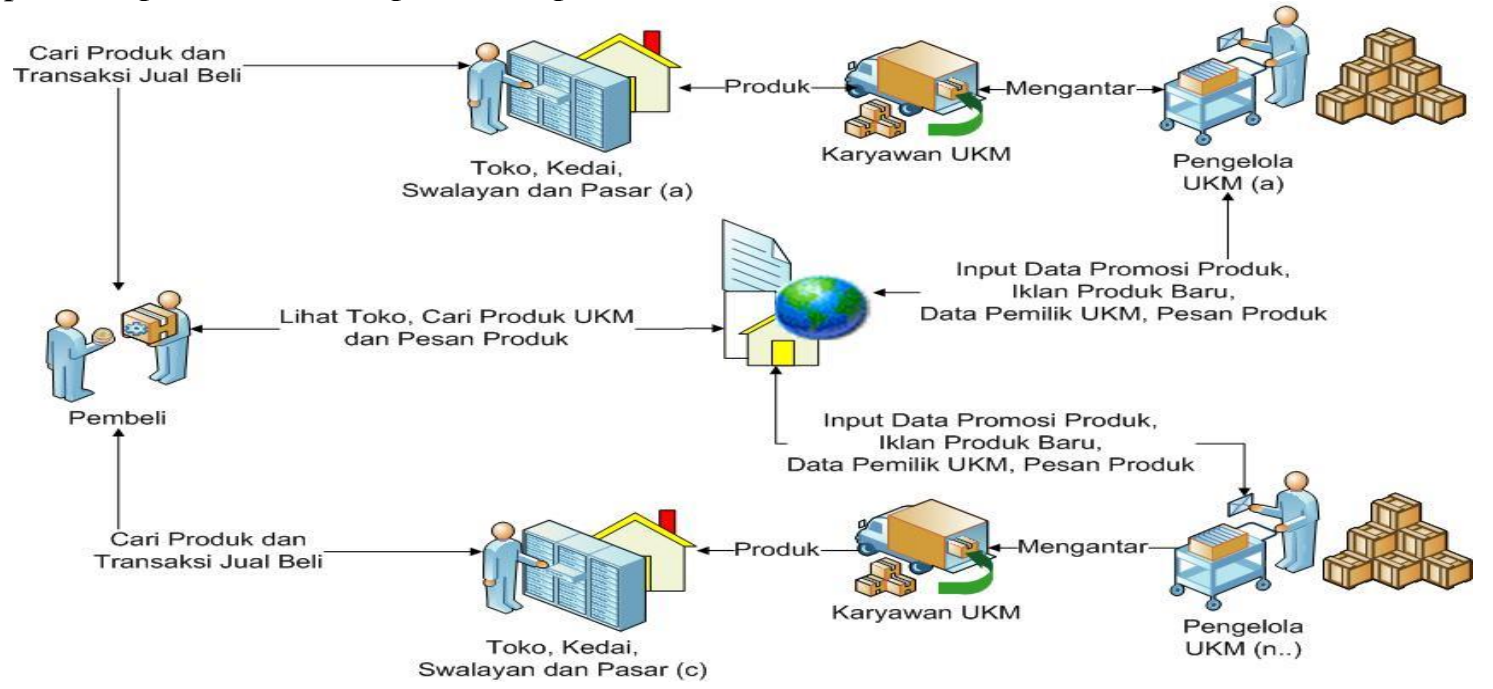

Gambar 3. Sistem Promosi Produk UKM

\subsection{Desain Sistem Informasi Promosi Produk UKM}

Halaman utama sistem informasi promosi produk UKM berisi tentang informasi kategori produk, pencarian produk, UKM premium, produk unggulan, space iklan untuk produk baru serta informasi bagaimana cara mengiklankan produk dan informasi jasa pengiriman. Hal tersebut dapat dilihat pada Gambar 4.

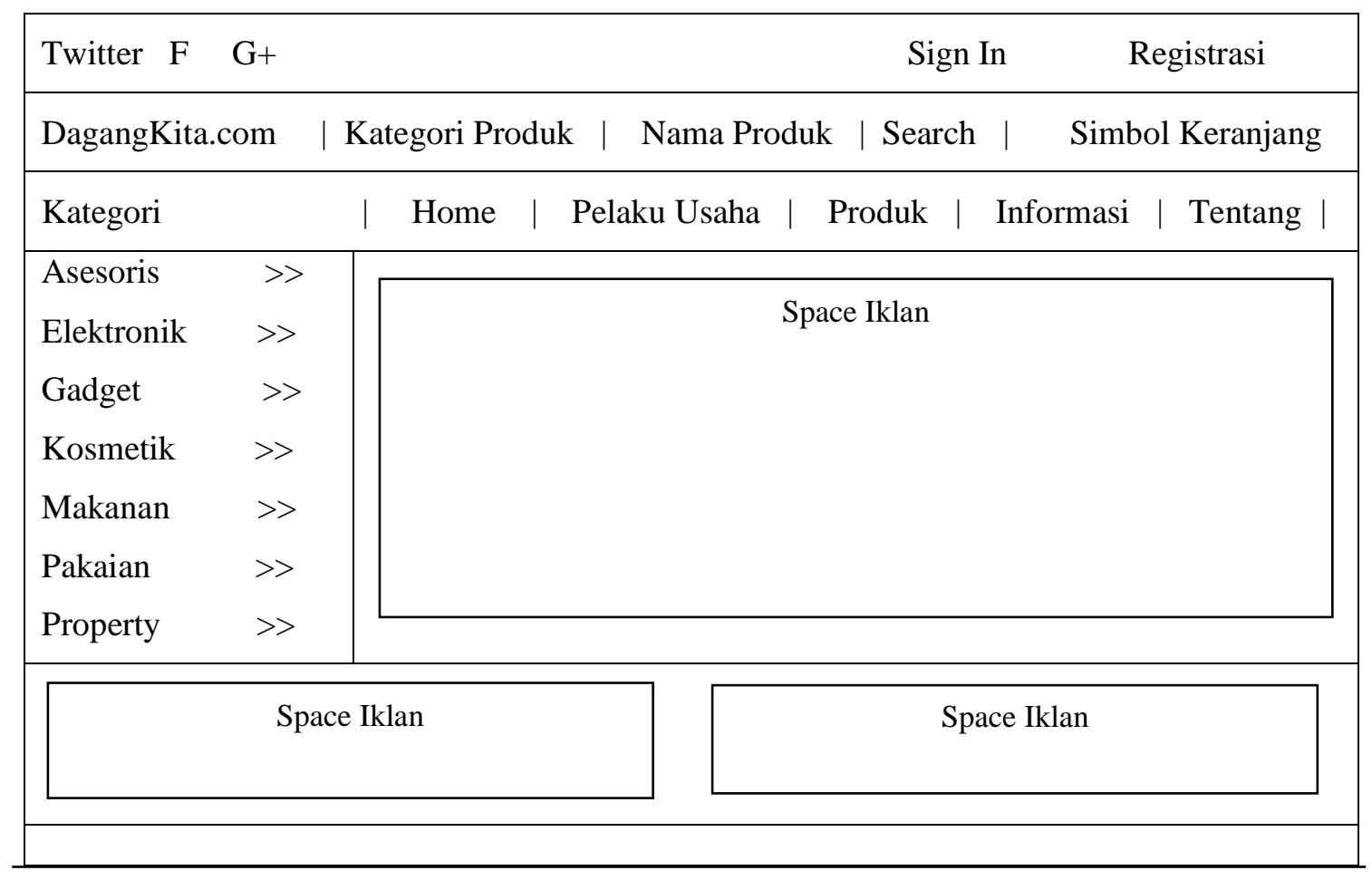




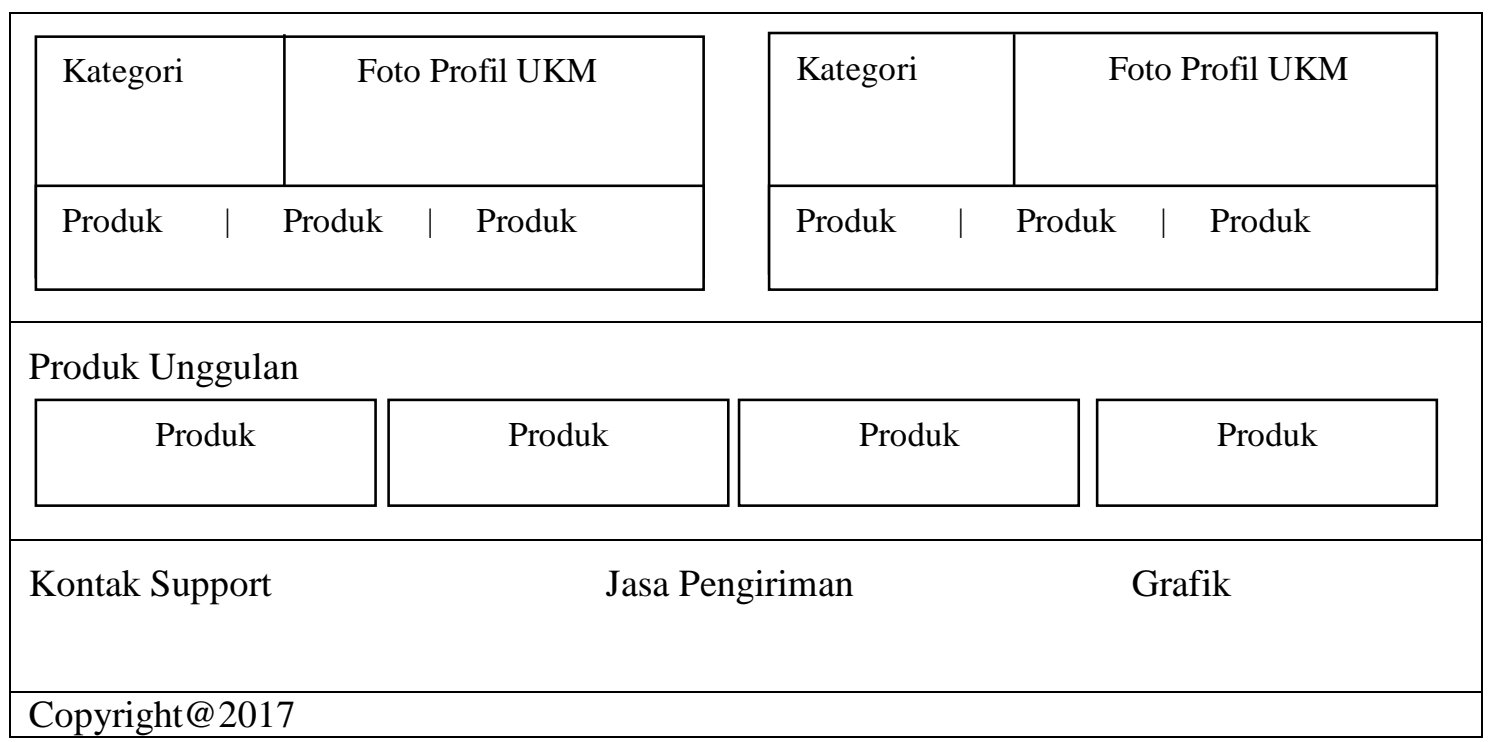

Gambar 4. Halaman Utama Sistem promosi Produk UKM

Desain interface website promosi produk untuk halaman administrator web. Pada halaman administrator terdiri dari logo dagangkita.com, registrasi, login, serta menu yang terdiri dari beberapa produk masing-masing UKM, hal tersebut dapat dilihat pada Gambar 5.

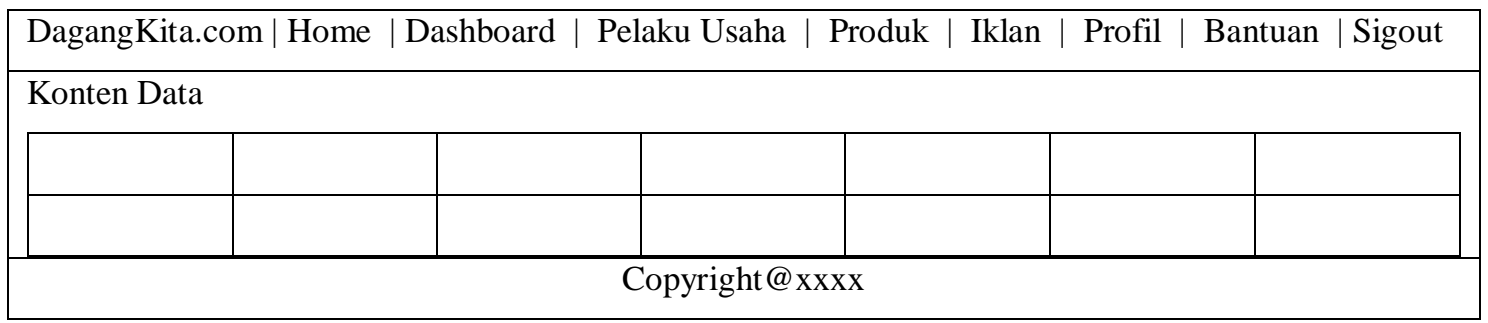

Gambar 5. Halaman administrator website

\subsection{Desain Database}

\subsubsection{Database promosi produk UKM secara konvensional}

Sistem penyimpanan (database) promosi produk UKM masih menggunakan manual dimana semua data produk disimpan pada komputer dalam bentuk file gambar dengan ektensi JPG, GIF, PNG dan Bitmap, kemudian data tersebut diletakkan pada UKM. Hal ini bertujuan untuk melayani pelanggan yang langsung datang ke UKM tersebut. Untuk lebih jelas dapat dilihat pada Gambar 6.

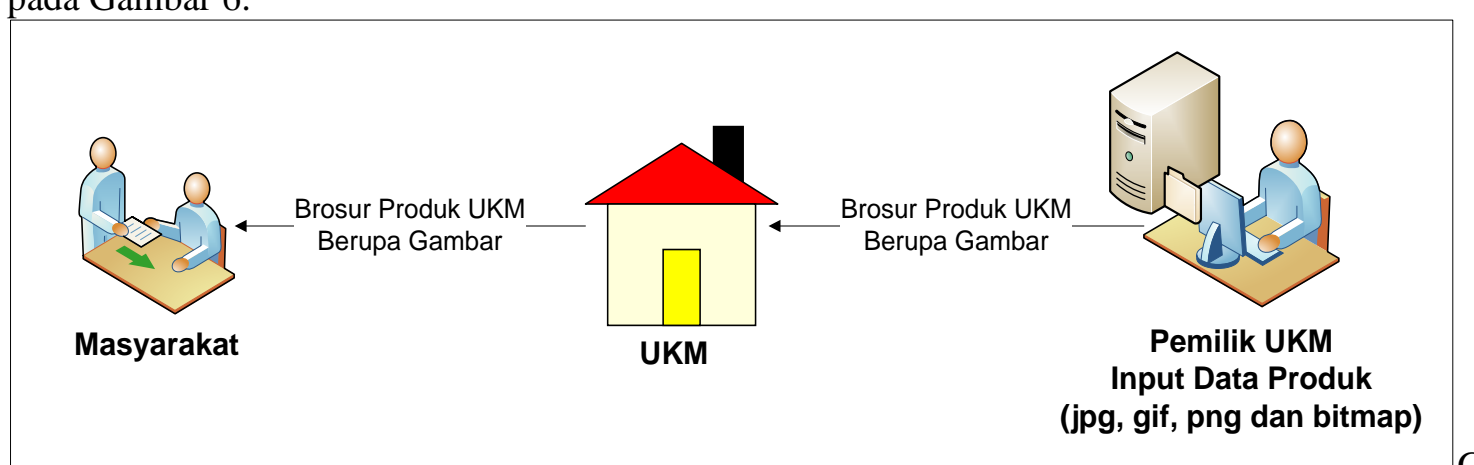

ambar 6. Sistem penyimpanan data produk UKM 


\subsubsection{Database promosi produk secara online}

Sistem penyimpanan data (database) promosi produk dirancang secara terpadu, guna untuk melakukan penyimpanan biodata UKM, produk, produk unggulan, UKM unggulan dan jasa iklan untuk produk baru. Database tersebut dapat menampung beberapa data UKM yang tergabung dalam rangka membantu mempromosikan produk masing-masing UKM secara online. Hal ini, juga memberikan pembelajaran bagi UKM dalam membiasakan diri untuk dapat mengikuti perkembangan teknologi informasi yang saat ini berkembang secara pesat. Adapun bagian yang terlibat pada sistem tersebut seperti administrator (pengelola sistem), UKM dan pengguna (masyarakat). Masing-masing bagian memiliki batasan hak akses yang berbeda-beda, misal administrator berfungsi untuk mengelola website dan manajemen data seluruh UKM yang tergabung pada sistem promosi berbasis web. UKM hanya dapat mengelola biodata, produk yang dimilikinya, sementara masyarakat dapat melihat semua produk UKM yang tergabung pada sistem yang disediakan, serta dapat menghubungi UKM melalui kontak person yang sudah disediakan. Hal tersebut dapat dilihat pada Gambar 7.

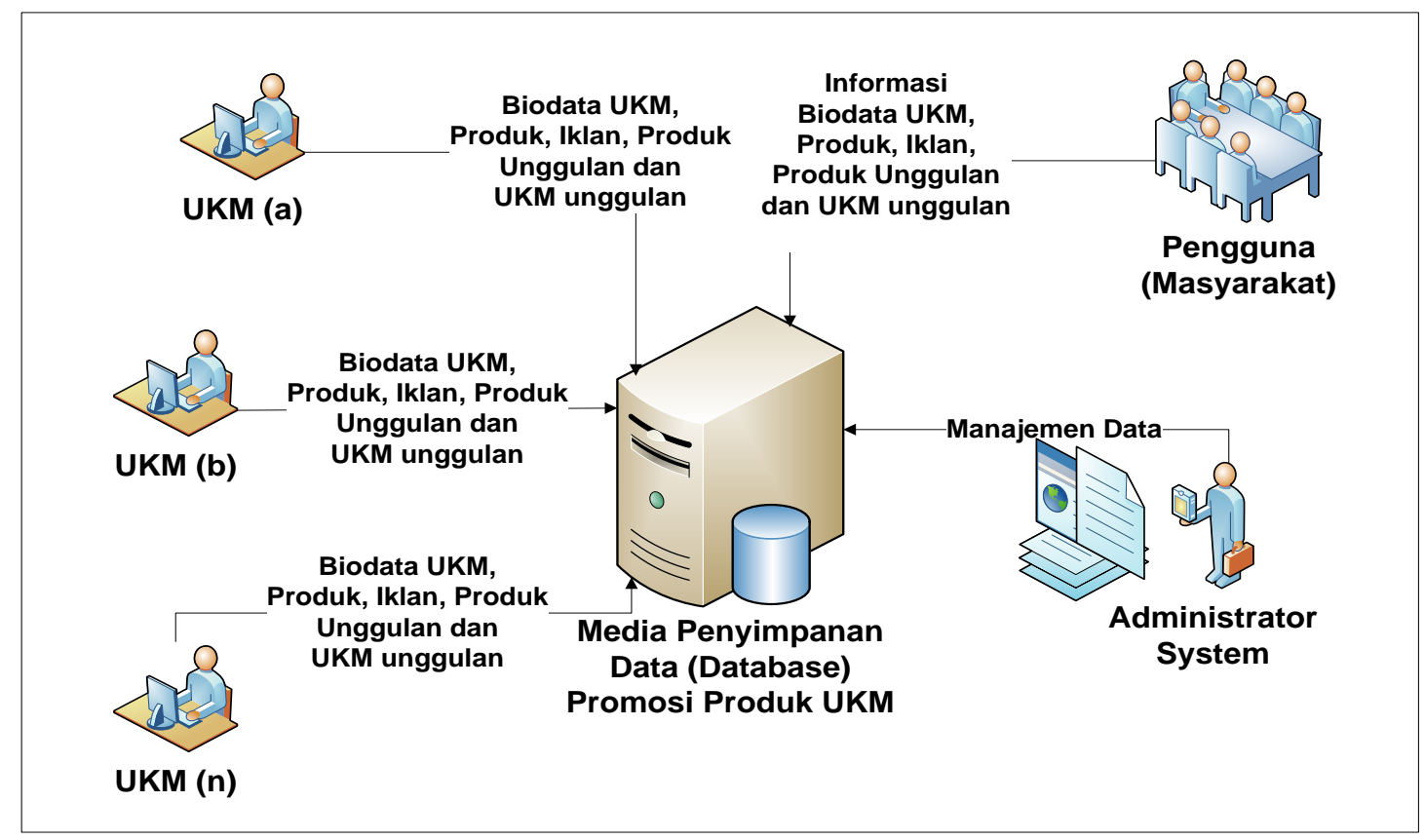

Gambar 7. Sistem penyimpanan database media promosi produk UKM

\subsubsection{Desain Database Konseptual}

Perancangan konseptual membahas tentang membangun sebuah model dari data yang digunakan untuk sistem dalam merancang database secara logikal dan pisikal. Dalam perancangan konseptual akan dibahas mengenai entity relationship (ER) yang dapat menggambarkan data secara lengkap. Hal tersebut dapat dilihat pada Gambar 8. 


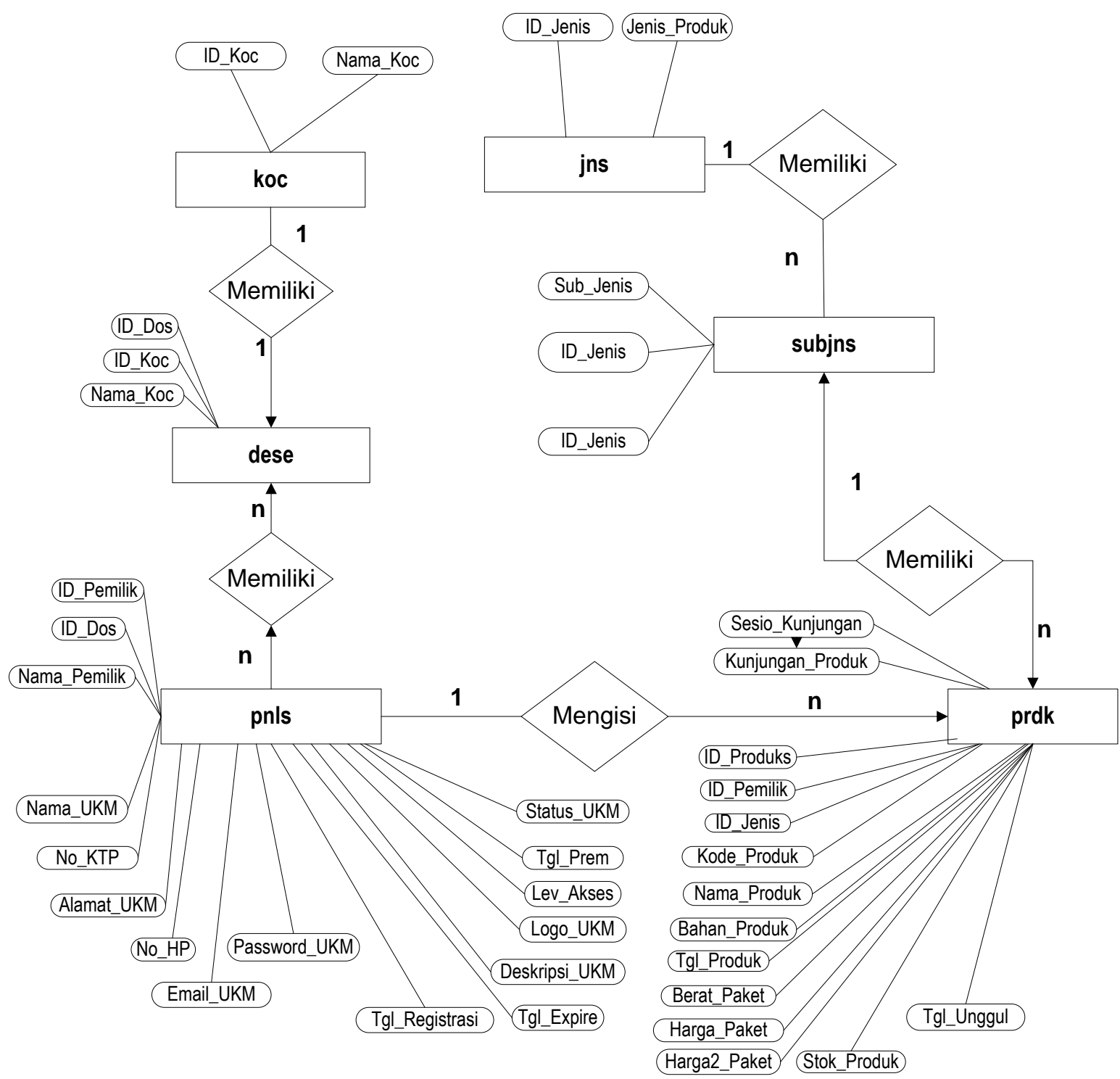

Gambar 8. Desain database secara konseptual

\subsection{Usecase Diagram}

Pada usecase diagram untuk desain sistem informasi promosi produk UKM melibatkan tiga aktor yaitu administrator sistem berfungsi untuk mengelola database dan website secara keseluruhan, melihat informasi, dan melakukan maintenance dalam hal update status UKM, produk unggulan, UKM premium dan status iklan. UKM berfungsi untuk registrasi, input data, update data, hapus data, pengajuan produk unggulan, UKM premium dan pengajuan promosi iklan. Sedangkan masyarakat (user) berfungsi untuk melihat informasi produk, UKM, dan melihat iklan yang ditawarkan oleh UKM serta dapat menghubungi UKM melalui kontak person yang sudah disiapkan. Untuk lebih jelas dapat dilihat pada Gambar 9. 


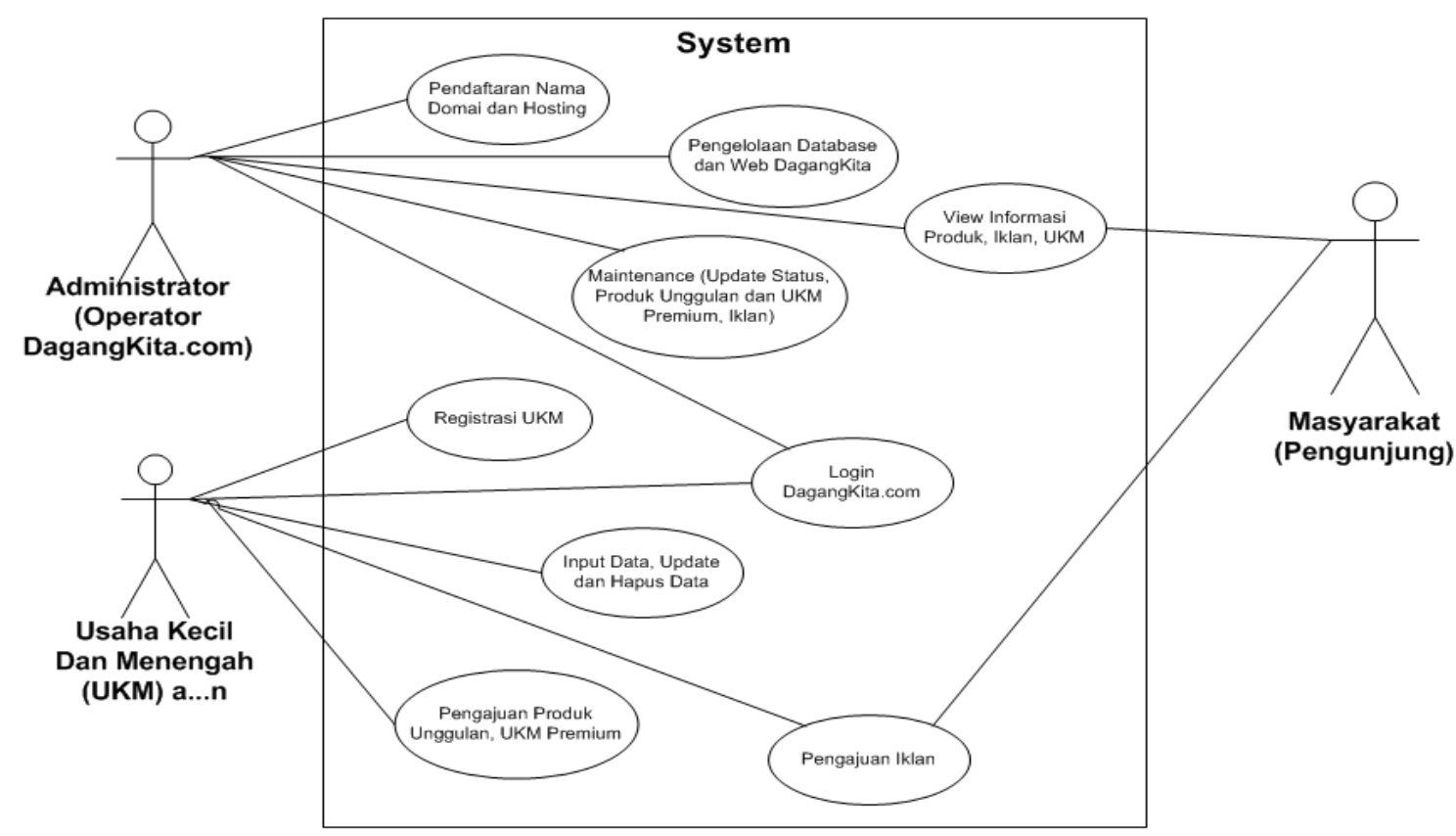

Gambar 9. Desain sistem informasi promosi produk UKM

\subsection{Activity Diagram}

Desain diagram aktivitas untuk melakukan registrasi pada aplikasi promoasi produk UKM melibatkan tiga bagian yaitu halaman web, system dan Operator aplikasi. Adapun tahapan dari bagian halaman web dimulai dengan masuk ke halaman web, klik menu registrasi, input data profil, data yang disimpan tersebut akan direspon oleh bagian system, kemudian bagian operator dapat melihat nama pelaku usaha atau UKM yang melakukan registrasi ke aplikasi promosi produk dan sekaligus mengaktifkan username dan password UKM tersebut. Untuk lebih jelas dapat dilihat pada Gambar 10.

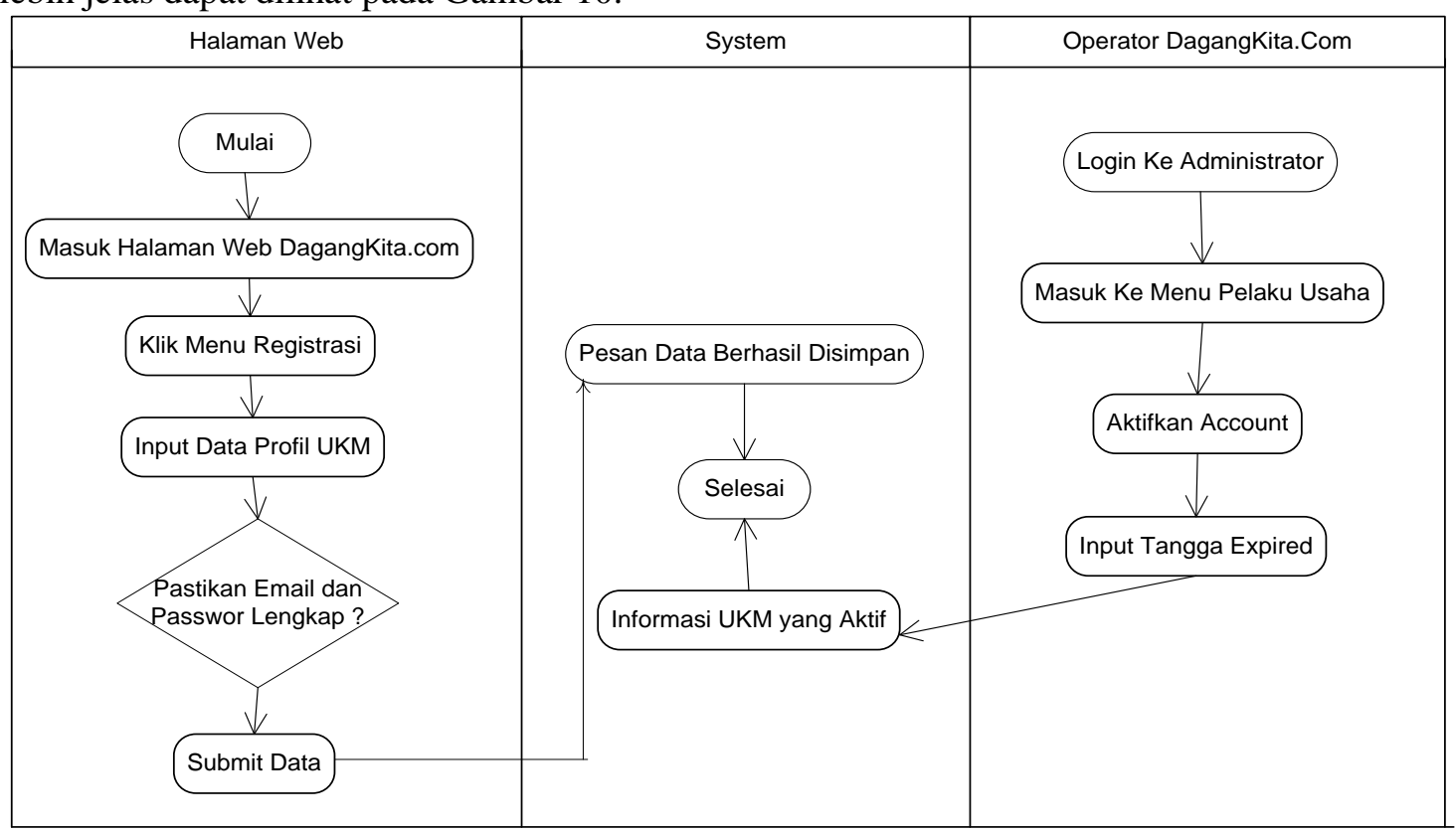

Gambar 10. Activity diagram untuk registrasi UKM 
Gambar 11 menjelaskan tentang diagram aktivitas untuk mengaktifkan UKM menjadi usaha premium dan produk unggulan pada halaman utama sistem promosi berbasis web. Ada dua bagian yang terlibat dalam melakukan hal tersebut yaitu UKM dan operator sistem. UKM dapat mengunjungi halaman web promosi, kirim SMS ke operator sistem, melakukan pembayaran ke bank, kemudian operator melihat data yang masuk sekaligus mengaktifkan menjadi usaha premium dan produk unggulan sesuai dengan permintaan UKM.

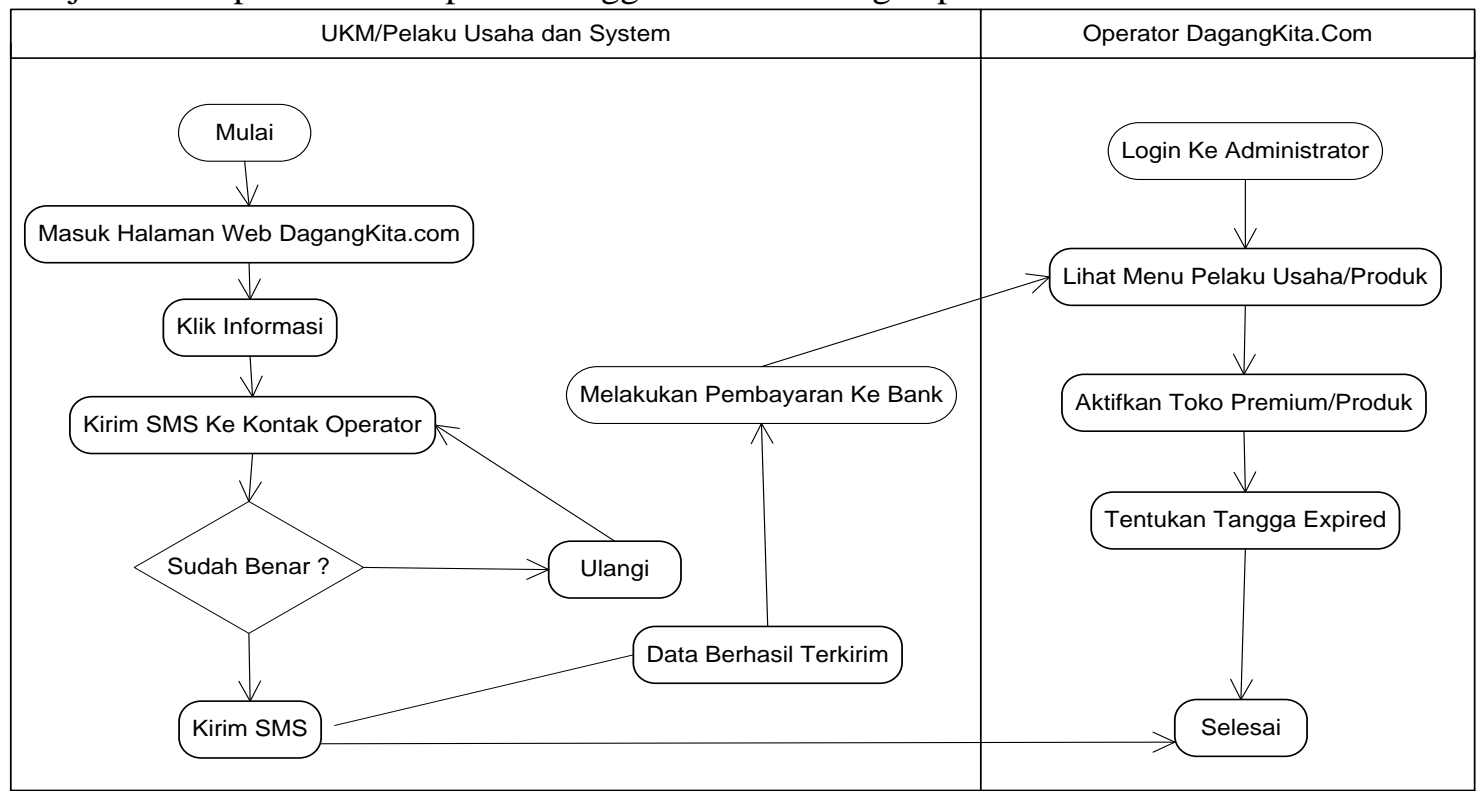

Gambar 11. Activity diagram untuk mengusulkan toko premium atau produk unggulan

\subsection{Hasil Desain Sistem Informasi Promosi Produk UKM}

Hasil perancangan interface sistem informasi promosi produk UKM dapat digunakan oleh banyak UKM sebagai media penyimpanan, penyampaian informasi atau memperkenalkan produk kepada masyarakat daerah dan masyarakat luar daerah melalui halaman utama website yang berisi tentang pencarian produk, kategori, toko premium, produk unggulan dan iklan. Hasil penelitian ini berupa aplikasi yang diberi nama dagangkita.com. Untuk lebih jelas dapat dilihat pada Gambar 12.

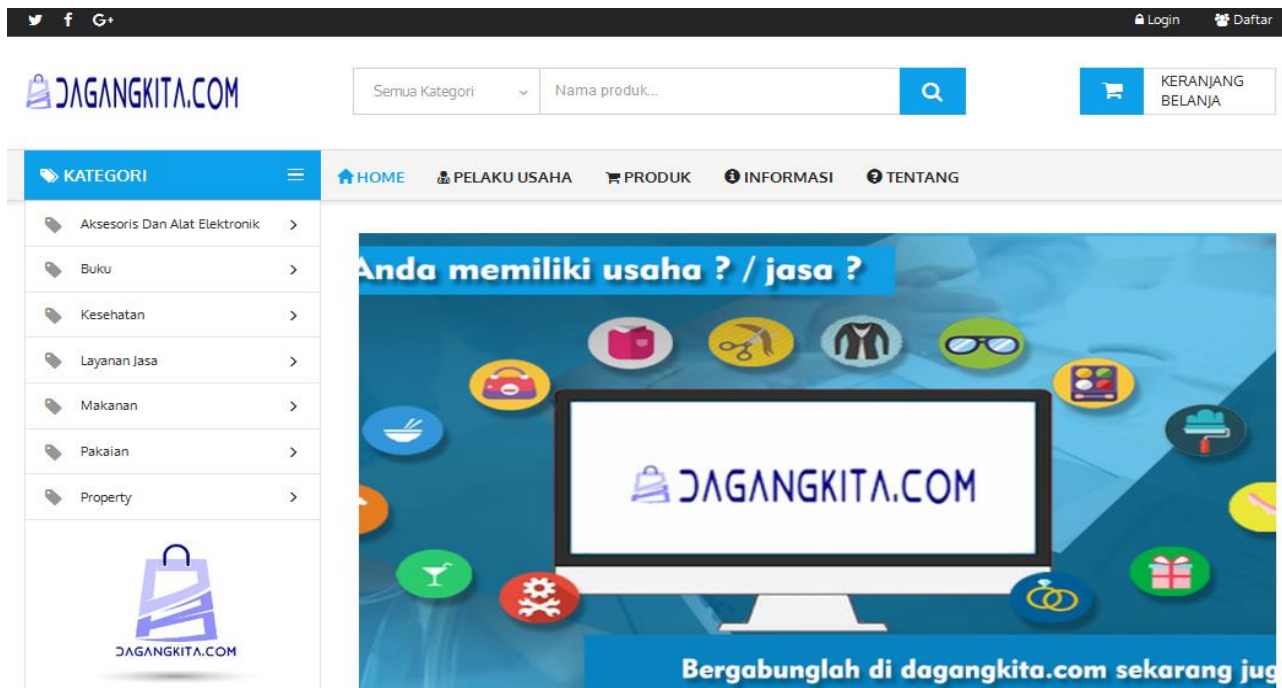

Gambar 12. Halaman utama sistem informasi promosi produk UKM 
Gambar 13 menjelaskan tentang daftar UKM yang ikut bergabung pada sistem informasi promosi produk.

\section{ENGNGEKTA.COM}

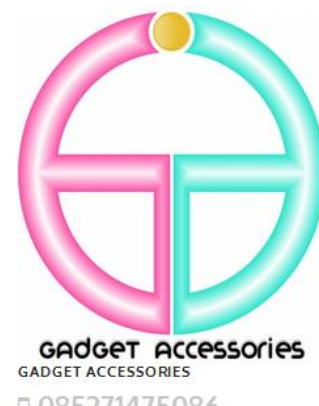

口 085271475086

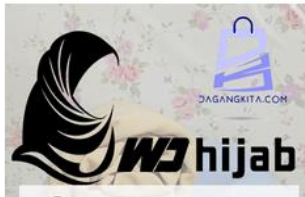

A HOME \&PELAKUUSAHA EPRODUK

(i) INFORMASI O TENTANG
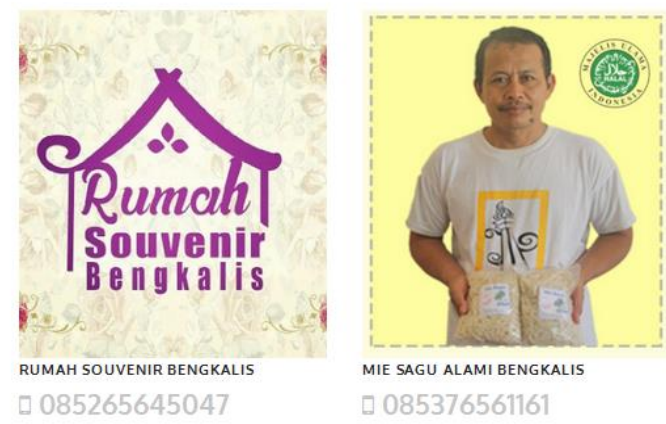

085376561161

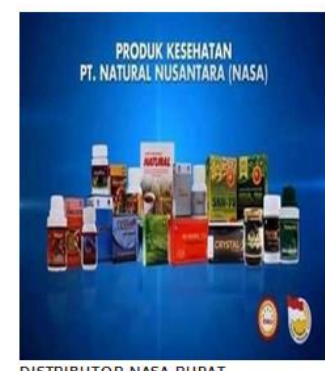

ISTRIBUTOR NASA RUPAT

口 085364728999
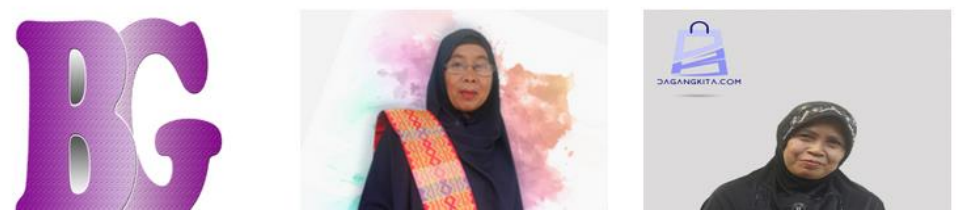

Gambar 13. Daftar UKM yang bergabung pada sistem informasi promosi

Gambar 14 menjelaskan tentang daftar produk UKM yang sudah bergabung pada sistem informasi promosi produk. Pada halaman ini menampilkan informasi tentang kategori produk, pencarian produk berdasarkan keinginan pengguna aplikasi dan menampilkan informasi lengkap terhadap produk tersebut.

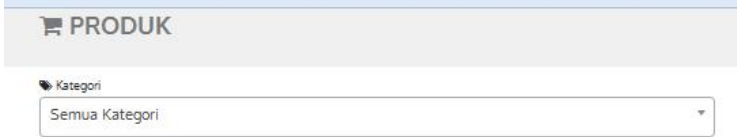

2

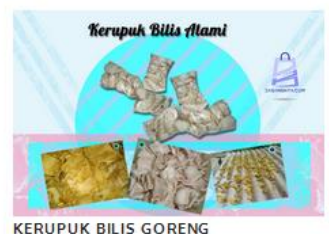

[] 081276703572

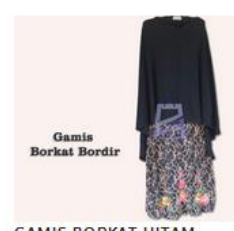

GAMIS BORKAT HITAM

gangkita.com.... 266111

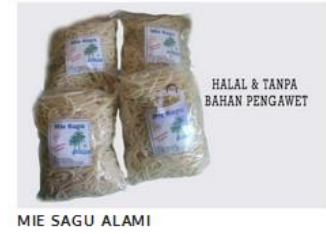

[] 085376561161

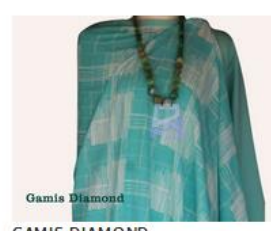

[ 085278266111

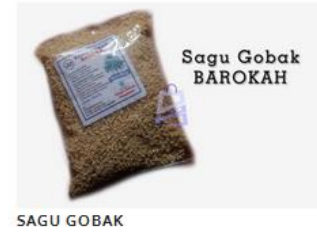

口 085376561161

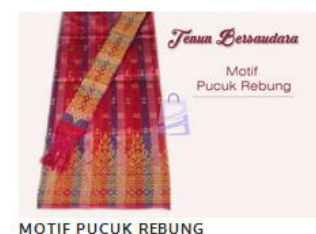

Q CARI

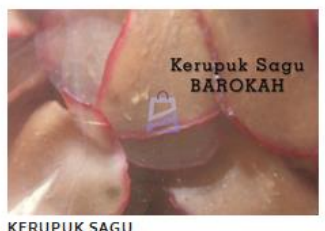

[a 085376561161

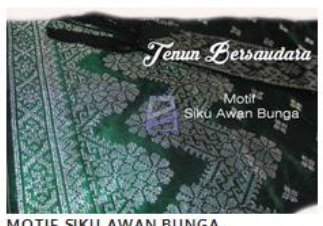

Gambar 14. Daftar Produk UKM yang bergabung pada sistem informasi promosi 
Gambar 15 menjelaskan tentang bagaimana UKM dapat melakukan registrasi sehingga dapat bergabung pada sistem informasi promosi produk.

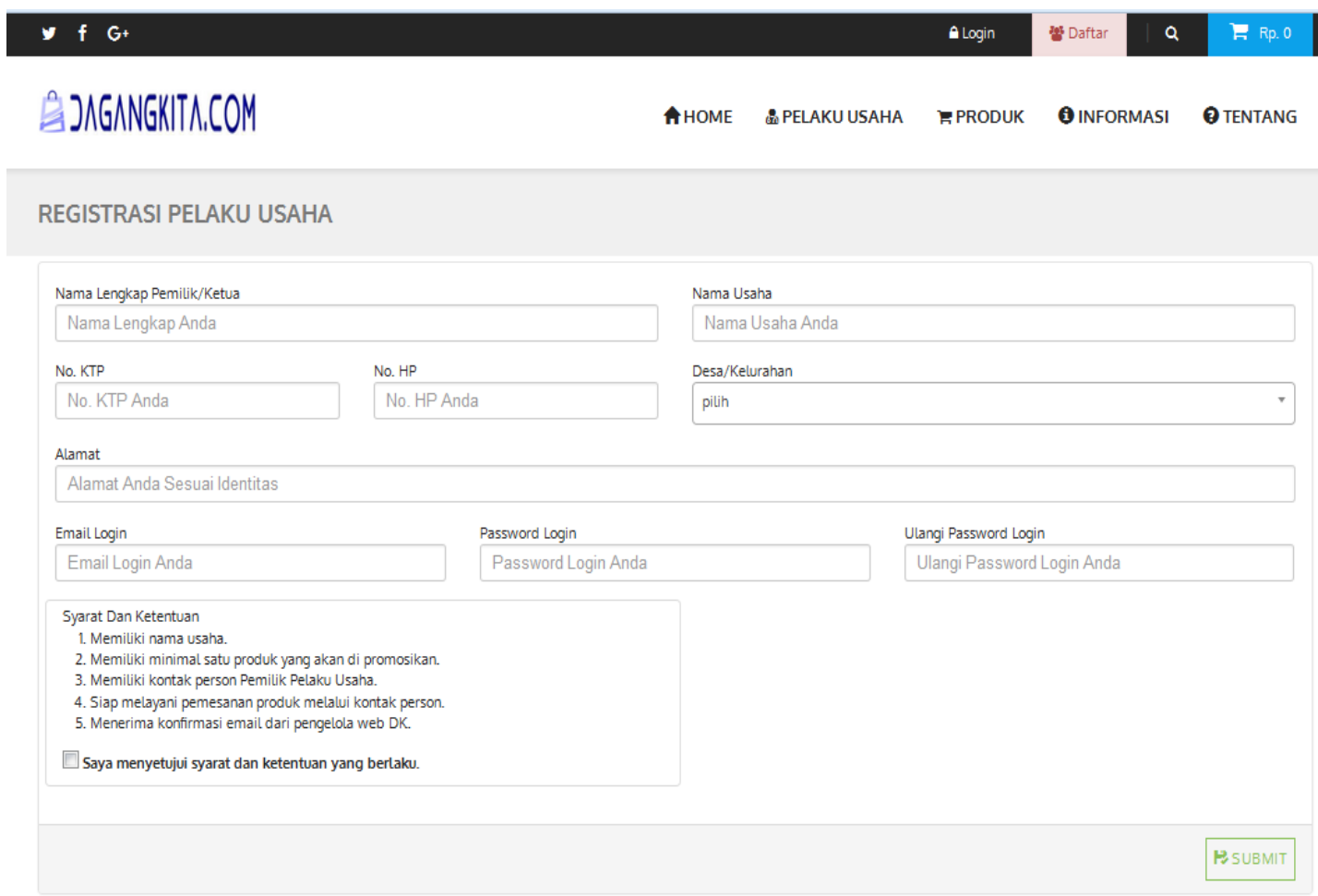

Gambar 15. Form Registrasi UKM pada sistem informasi promosi

\section{Kesimpulan}

Penelitian ini menghasilkan sistem promosi produk berbasis web yang dapat memaksimalkan pemasaran produk UKM. Sistem ini memberikan informasi produk unggulan, produk pada semua kategori dan promosi toko-toko yang berkaitan dengan produk UKM melalui akses internet. Sistem promosi produk ini dapat memberikan layanan transaksi bisnis pada UKM Kabupaten Bengkalis. Untuk meningkatkan tingkat pemahaman pelaku usaha UKM terhadap teknologi informasi perlu dilakukan pembinaan sumber daya manusia melalui pelatihan atau bimbingan teknis terkait sistem promosi produk berbasis IT.

\section{Daftar Pustaka}

[1] Hapsari, P. P., Hakim Abdul, dan Soeaidy Saleh, 2014, Pengaruh Pertumbuhan Usaha Kecil Menengah (UKM) Terhadap Pertumbuhan Ekonomi Daerah (Studi di Pemerintahan Kota Batu), Wacana, Vol. 17, No. 2, 88-96

[2] Tambunan, T. T (2012), Peluang Tantangan Dan Ancaman Bagi Umkm Indonesia Dalam Era Cafta Dan Me-Asean 2015, Prosiding Seminar \& Konferensi Nasional Manajemen Bisnis, Universitas Muria Kudus, Jawa Tengah

[3] Admin UKM Riau (2016), Data Serta Jumlah UKM Kota Pekanbaru dan Riau, Portal Bisnis dan Direktori UKM Indonesia, UKM Riau.

[4] Hariadi, D (2012) Pengaruh Produk Harga, Promosi dan Distribusi Terhadap Keputusan Pembelian Konsumen pada Produk Projector Microvision, Jurnal Ilmu \& Riset Manajemen, Vol. 1 No. 8

[5] Swastha B. dan Irawan (2005), Asas-asas Marketing, Liberty, Yogyakarta

[6] Alma B. (2004), Manajemen Pemasaran dan Pemasaran Jasa, Alfabeta, Bandung 
[7] Goenadhi L (2011) Faktor-Faktor yang Mempengaruhi Perilaku Konsumen dalam Keputusan Pembelian Mobil Toyota Avanza di Kota Banjarmasin, Jurnal Manajemen dan Akutansi, Vol 12 No 2.

[8] Novita D (2016) "Studi Keberhasilan UKM Melalui Perdagangan Online B2B dan B2C", ISBN : 978-602-72850-1-9, KNIT-2 Nusa Mandiri, Jakarta

[9] Fitri D.A, Kasmawi, dan Mansur (2017) Desain Sistem Promosi Produk Usaha Kecil Menengah (UKM) Menggunakan Model Business to Cosumer (B2C), Seminar Nasional Industri dan Teknologi (SNIT) Politeknik Negeri Bengkalis, ISSN : 2303-2790

[10] Syahputri, W. dan Mansur (2018) Desain Prototipe Sistem Jual Beli Online Produk UMKM Bengkalis Berbasis Andorid, Jurnal Ilmiah Ilmu Komputer, Vol. 4, No. 1, ISSN : 2442-4512 